\title{
Stable isotope composition of Chara rudis incrustation in Lake Jasne, Poland
}

\author{
M. Pełechaty $\cdot$ K. Apolinarska $\cdot$ A. Pukacz $\cdot$ \\ J. Krupska $\cdot$ M. Siepak $\cdot$ P. Boszke $\cdot$ \\ M. Sinkowski
}

Published online: 18 September 2010

(C) The Author(s) 2010. This article is published with open access at Springerlink.com

\begin{abstract}
Stable isotope composition $\left(\delta^{13} \mathrm{C}\right.$ and $\delta^{18} \mathrm{O}$ ) was analysed in mineral incrustation of Chara rudis and surrounding waters. This macroalga forms dense and extensive charophyte meadows and may significantly contribute to the calcium carbonate precipitation and deposition of marl lake sediments. The study aimed to find out if charophyte calcium carbonate was precipitated in an isotopic equilibrium with lake water and if the precipitation was related to the environmental conditions. Two apical internodes of 10 individuals of $C$. rudis were collected monthly between June and late October 2008 at three
\end{abstract}

Guest editors: A. Pieterse, S. Hellsten, J. Newman, J. Caffrey, F. Ecke, T. Ferreira, B. Gopal, J. Haury, G. Janauer,

T. Kairesalo, A. Kanninen, K. Karttunen, J. Sarvala,

K. Szoszkiewicz, H. Toivonen, L. Triest, P. Uotila, N. Willby / Aquatic Invasions and Relation to Environmental Changes: Proceedings of the 12th International Symposium on Aquatic Weeds, European Weed Research Society

\author{
M. Pełechaty $(\bowtie) \cdot$ J. Krupska $\cdot$ P. Boszke . \\ M. Sinkowski \\ Department of Hydrobiology, Faculty of Biology, Adam \\ Mickiewicz University, Umultowska 89, 61-614 Poznan, \\ Poland \\ e-mail: marpelhydro@poczta.onet.pl \\ J. Krupska \\ e-mail: jkrupska@poczta.onet.pl \\ P. Boszke \\ e-mail: hydropati007@wp.pl \\ M. Sinkowski \\ e-mail: sinymaciek@o2.pl
}

permanent study sites $(1.0 \mathrm{~m}, 1.5 \mathrm{~m}$ and $2.0 \mathrm{~m}$ deep) in a small (15.1 ha) and shallow (mean depth: $4.3 \mathrm{~m}$ ) mid-forest lake with extensively developed charophyte meadows (Lake Jasne, mid-Western Poland). Basic physical-chemical analyses were performed at each study site, and water samples for further laboratory determinations, including stable isotope analyses, were collected from the above searched $C$. rudis stands and, simultaneously, at three comparative sites in the macrophyte-free pelagial. The difference in $\delta^{13} \mathrm{C}$ between incrustation and water from above $C$. rudis exceeded 2\%o V-PDB at each site. In the case of $\delta^{18} \mathrm{O}$, it exceeded $2 \%$ between July and September. Accordingly, it is postulated that calcium carbonate was not precipitated in an isotopic equilibrium with lake water. Incrustation was enriched in heavier carbon isotope, ${ }^{13} \mathrm{C}$, and water was enriched in ${ }^{18} \mathrm{O} . \delta^{13} \mathrm{C}$ of incrustation and DIC were positively correlated, whereas negative relation

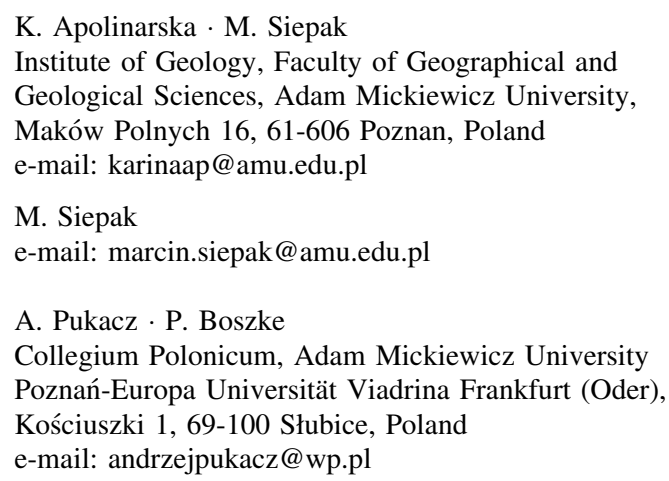


was found between $\delta^{18} \mathrm{O}$ of incrustation and water. Several dependencies were found with water chemistry above the plants. The content of mineral incrustation in Chara dry weight had negative influence on the $\delta^{18} \mathrm{O}$ but not on the $\delta^{13} \mathrm{C}$. Community depth, structure and PVI had no effect. No significant differences appeared between isotope composition in the pelagic zone and Chara stands.

Keywords Stable isotopes $\cdot \delta^{13} \mathrm{C} \cdot \delta^{18} \mathrm{O}$. Incrustation · Charophytes

\section{Introduction}

Water bodies giving rise to lake sediments containing high proportion of carbonates are widely distributed over the continents and are referred to as marl lakes (Coletta et al., 2001). The main mechanisms of autochthonous marl precipitation are photosynthetic activities of aquatic macrophytes, in the littoral zone (Wetzel, 1960), and phytoplankton, particularly autotrophic picoplankton, in the pelagic zone (Yates \& Robbins, 1998; Dittrich \& Obst, 2004; Dittrich et al., 2004). In shallow macrophyte lakes, plants covering most of the lake basin reveal the leading role in the biomass production in contrast to deep stratified lakes, in which phytoplankton takes over the majority of photosynthetic productivity (Alimov, 2003). Among aquatic macrophytes, charophytes (stoneworts), green macroscopic algae belonging to the family Characeae, can be considered important in the calcium carbonate precipitation. They use soluble bicarbonates from the lake water and, by removing $\mathrm{CO}_{2}$ that can be photosynthetically assimilated, convert them into the insoluble calcium carbonate (McConnaughey, 1997). By carbonate deposition directly onto the surface of their thalli, charophytes become encrusted (Raven et al., 1986). Although, all photosynthetic plants are capable of precipitating calcium carbonate, the carbonate is usually dispersed (Coletta et al., 2001). Mineral incrustation, exhibiting a specific zonation on the plant surface, to be seen even with a naked eye, is a feature typical of charophytes (e.g., Groves \& Bullock-Webster, 1924; Krause, 1997; Schubert \& Blindow, 2003), whose effectiveness to use bicarbonates over a wide range of concentrations in the water is higher as compared to vascular plants (van den Berg et al., 1999). Depending on the species, charophytes can be slightly (e.g. Nitella species) or heavily (most of Chara species) encrusted and the thallus morphology (corticate or ecorticate) as well as growth conditions (mainly calcium and bicarbonate availability) can be assumed as significant differentiating factors (Dąmbska, 1964; Krause, 1997). According to Hutchinson (1975), carbonate incrustation can reach up to $60 \%$ of the charophyte dry weight. Therefore, large amounts of the carbonates precipitated by charophytes can be preserved in sediments being a visualization of bicarbonate uptake during intensive growth (Kufel \& Kufel, 2002 and references therein) and important record of environmental changes (Dittrich \& Obst, 2004).

The study of ${ }^{13} \mathrm{C} /{ }^{12} \mathrm{C}$ and ${ }^{18} \mathrm{O} /{ }^{16} \mathrm{O}$ stable isotope ratios in lacustrine carbonates can reflect environmental conditions under which the carbonates were precipitated and incrustations of modern charophytes can be helpful in interpretation of these archives. However, the relation between carbon and oxygen isotope composition in modern Chara incrustations and $\delta^{18} \mathrm{O}$ in water and $\delta^{13} \mathrm{C}$ in DIC (dissolved inorganic carbon) must be well understood. Although few papers dealt with the problem (e.g. Coletta et al., 2001; Andrews et al., 2004; Pentecost et al., 2006), there is still a need to explore the relation of isotope values between different Chara species and water parameters. Investigations of the dynamics of the stable isotope composition of charophyte incrustation throughout the growth season, in addition to information on incrustation-environment interdependencies are required. We investigated the composition of $\delta^{13} \mathrm{C}$ and $\delta^{18} \mathrm{O}$ in the calcite incrustation of Chara rudis $\mathrm{A}$. Braun in Leonhardi, a large charophyte species, up to $80 \mathrm{~cm}$ long, having a diplostichous cortex with highly variable diameter of primary and secondary cortex cells, and spine-cells in bunches, particularly densely developed on the younger, apical part of the plants; a double whorl of well developed stipulodes as well as numerous branches and branchlets which may provide large surface areas for adsorption. Although the species is not common, it is widely distributed in European nutrient-poor fresh waters, where it regularly forms extensive underwater carpets, significantly contributing to the submerged vegetation (Groves \& Bullock-Webster, 1924; Dąmbska, 1964; Krause, 1997). Our study was 
performed in a lake overgrown by extensive charophyte meadows, with a dominance of the abovementioned $C$. rudis. Charophytes may be considered responsible for the lake's primary production and precipitation of marls (Pełechaty et al., 2007). We tried to find out (i) if calcium carbonate was precipitated by $C$. rudis in an isotopic equilibrium with the lake's waters and (ii) if the carbonate precipitation was related to the changing environmental conditions or site-specific.

\section{Study lake and vegetation}

The study was performed in a charophyte-dominated Lake Jasne $\left(52^{\circ} 17^{\prime} 7^{\prime \prime}, 15^{\circ} 03^{\prime} 6^{\prime \prime}\right)$ localized in a mesoregion of Torzym Plain (Lubuskie Lakeland, mid-Western Poland, Fig. 1). The lake is placed in the southern part of postglacial Gronów-RzepinTorzym tunnel-valley, about $3 \mathrm{~km}$ south of a small town-Torzym. It is a temporary outlet, postglacial lake with an area of 15.1 ha and maximal and mean depths of $9.5 \mathrm{~m}$ and $4.3 \mathrm{~m}$, respectively (Jańczak, 1996). The direct drainage basin of the lake constitutes a partial catchment of the left-side tributary of the Ilanka River. Over $90 \%$ of the drainage basin is covered by forest (mostly pine forest), preventing intense erosion of steep slopes and substantial input of terrestrial material into the lake. During the summer season, Lake Jasne is used for recreational purposes.

Lake Jasne belongs to a group of shallow lakes (with no fully developed vertical stratification). It is one of the clearest lakes within Lubuskie Lakeland, characterized by visibility (Secchi depth) exceeding $5 \mathrm{~m}$. Low nutrient concentrations and phytoplankton productivity are reflected in a low value of Carlson's (1977) trophy state index, typical of mesotrophic lakes (Pełechaty et al., 2007). The bottom slope in the lake is mild, but rushes develop sparsely and form only a narrow belt in the littoral zone. However, it offers good conditions for the development of submerged vegetation composed of charophyte meadows, comprising up to $60 \%$ of the lake area (Pełechaty et al., 2007). Most of the vegetated area is dominated by $C$. rudis and $C$. tomentosa $\mathrm{L}$. communities. Generally, six charophyte communities were distinguished. Moreover, charophytes defined the

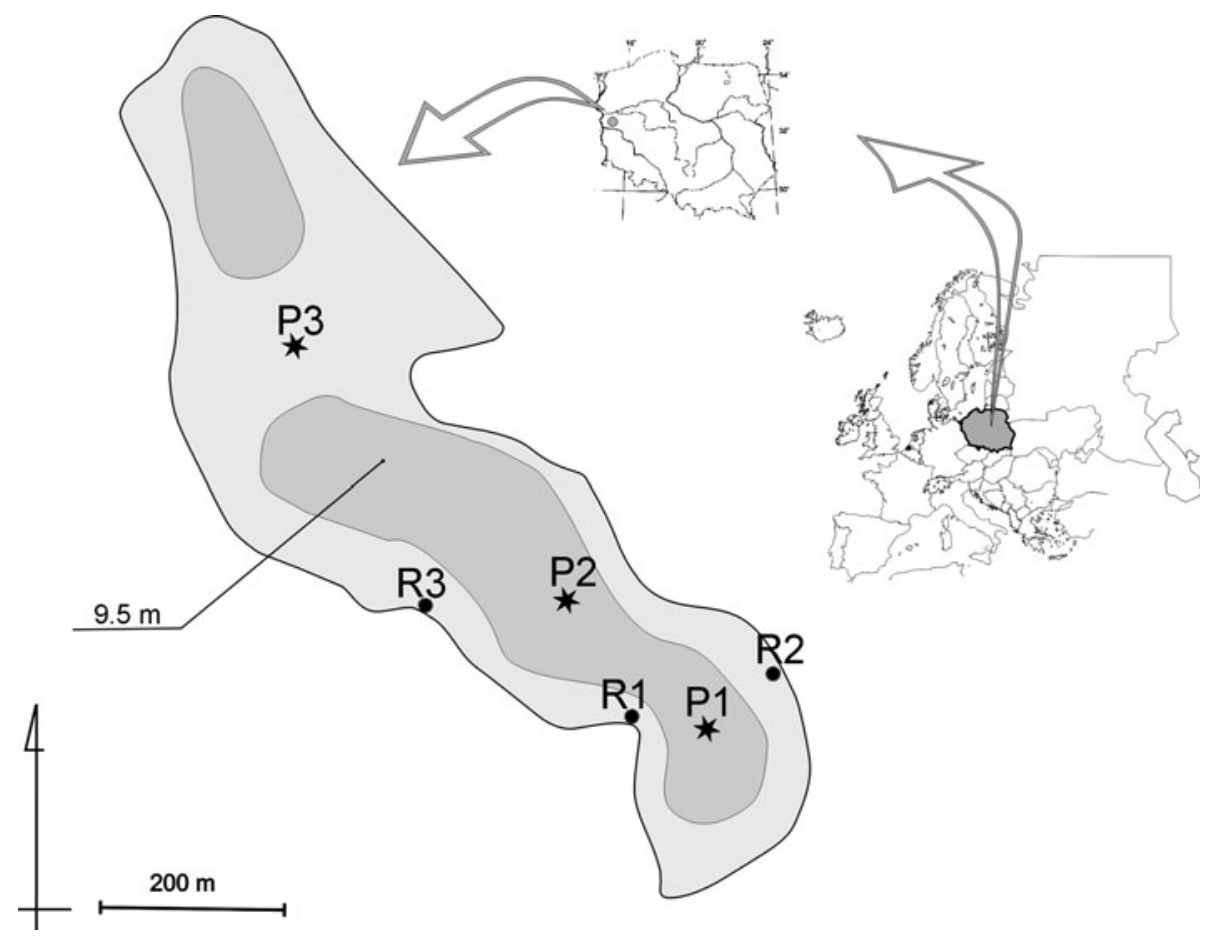

Fig. 1 Location of Lake Jasne (mid-Western Poland) and site distribution. R1-R3: sites in C. rudis beds, $P 1-P 3$ : macrophyte-free pelagic zone sites 
maximum depth extent of vegetation in Lake Jasne, reaching $7.9 \mathrm{~m}$. With the exception of rushes, the percentage share of other vascular vegetation is negligible.

\section{Study sites and methods}

Samples of $C$. rudis and water from above the plants were collected monthly between June and late October 2008 at three permanent study sites (R1, $\mathrm{R} 2$ and R3) with an area of $25 \mathrm{~m}^{2}$ each, located in the middle of extensive stands of $C$. rudis (Fig. 1). The species coverage reached up to $100 \%$ at each site. The sites differed with respect to the depth (R1: $2.0 \mathrm{~m}, \mathrm{R} 2: 1.0 \mathrm{~m}$ and R3: $1.5 \mathrm{~m}$ ). Prior to charophyte sampling, basic physical-chemical analyses of water above the studied charophyte patches, including water temperature, oxygen concentration, conductivity and $\mathrm{pH}$ were performed by means of portable field measurement equipment (Elmetron CX-401, CyberScan 200, CyberScan 20, respectively). Then, water samples for further laboratory analyses were collected with $1 \mathrm{~L}$ plastic bottles and preserved with chloroform. Water samples for isotope analyses were collected with two 10-ml glass septa test-tubes and preserved with $\mathrm{HgCl}_{2}$. Three comparative sampling sites were situated in the macrophyte-free pelagial zone (Fig. 1), at which field analyses were supplemented with Secchi depth measurements. At each sampling site, field measurements and water sampling were performed at the depth of $0.5 \mathrm{~m}$.

During each sampling event the structure and species composition of $C$. rudis patches were studied with the use of the commonly applied, mid-European phytosociological method of Braun-Blanquet (1964). This method is based on phytosociological data recorded in representative patches of vegetation with the use of phytosociological relevés (records). In each sampled patch species composition was determined, and the proportion of sampling area covered by each species was assessed. Based on this it became obvious that $C$. rudis was the absolute dominant in each studied patch, and a few other species recorded were of negligible contribution. Then, percentage volume infested by plants (PVI) was calculated as the product of the percentage of coverage of the plants and their height divided by the depth, at which the patch developed. Ultimately, 10 C. rudis individuals were collected at each study site. The plants were transported to the laboratory where the length of the main axis (stem) was measured, and the number of branches was counted. The two features were taken under consideration as they could have possibly influenced the PVI values and, thus, the rate of photosynthesis and encrustation intensity. The biometric measurements were carried out until September. After that time, the charophyte decomposition started. According to Andrews et al. (1984) the most intense photosynthetic activity is restricted to the apex of the charophyte thallus. We observed in our unpublished biometric study that the mean monthly growth rate of the main axis was equal to the length of two internodes. As a result of this observation, two apical internodes (approximately $5 \mathrm{~cm}$ long segments) of the main axis were separated from each of these 10 individuals. The apices were stored in paper bags and air-dried at room temperature (one week, approximately $21^{\circ} \mathrm{C}$ ). Analysis of the percentage contribution of $\mathrm{CaCO}_{3}$ of the total weight of $C$. rudis apices began with weighing the dried material using a RADWAG WPA 180/C/I with resolution of $0.0001 \mathrm{~g}$. Apices with calcite coatings were placed in $30 \% \mathrm{H}_{2} \mathrm{O}_{2}$ for $48 \mathrm{~h}$ and boiled for $30 \mathrm{~min}$, resulting in a loss of most of the organic matter by dissolution. The remaining $\mathrm{CaCO}_{3}$ encrusted material was stirred and pressed in order to separate calcite and organics. The solution was passed through a sieve and evaporated at $40^{\circ} \mathrm{C}$. The carbonate residue was weighed. Stable isotope composition was determined on the organic matterfree material in the Stable Isotope Laboratory, Institute of Geology and Mineralogy, University of Erlangen, Germany. Carbonates were dissolved using $100 \%$ phosphoric acid (density $>1.9$, Wachter \& Hayes, 1985) at $75^{\circ} \mathrm{C}$ using a Kiel III online carbonate preparation line connected to a ThermoFinnigan 252 masspectrometer. All values are reported per mil relative to $\mathrm{V}-\mathrm{PDB}$ by assigning a $\delta^{13} \mathrm{C}$ value of $+1.95 \%$ and a $\delta^{18} \mathrm{O}$ value of $-2.20 \%$ to NBS 19 . Reproducibility was checked by replicate analysis of laboratory standards and was better than \pm 0.06 and $0.08 \%$, for $\delta^{13} \mathrm{C}$ and $\delta^{18} \mathrm{O}$, respectively. For correct interpretation of the isotope record, it is essential to know if the precipitated $\mathrm{CaCO}_{3}$ consists of calcite or aragonite. In neither sample was aragonite detected.

Stable isotope composition in the lake water was determined in the Laboratory of Analytical and Environmental Chemistry, Vrije Universiteit Brussel, 
Belgium. Details of analytical methods are in Gillikin \& Bouillon (2007). All data are expressed in \%o relative to VSMOW $(0.0 \%$ ) on a scale normalized so that standard light Arctic precipitation (SLAP) is exactly $55.5 \%$. The precision was better than $0.15 \%$ o $(1 \sigma)$, determined by repeated analyses of the seawater and tap-water standards and replicate sample analyses.

Water samples collected in the field for further chemical analyses were stored in the refrigerator and analyzed under laboratory conditions. In order to determine anions $\left(\mathrm{Cl}^{-}, \mathrm{NO}_{3}{ }^{-}, \mathrm{NO}_{2}{ }^{-}, \mathrm{SO}_{4}{ }^{2-}, \mathrm{PO}_{4}{ }^{3-}\right)$ and cations $\left(\mathrm{Na}^{+}, \mathrm{NH}_{4}{ }^{+}, \mathrm{K}^{+}, \mathrm{Ca}^{2+}, \mathrm{Mg}^{2+}\right)$ in water samples a Metrohm ion chromatograph, the 881 Compact IC Pro model (Metrohm, Switzerland) was applied. Metrosep A Supp 4/5 Guard (the guard column) and Metrosep A Supp 5 (the separating column) were used for the determination of anions The mobile phase employed was $3.2 \mathrm{mmol} \mathrm{Na}_{2} \mathrm{CO}_{3} /$ $1.0 \mathrm{mmol} \mathrm{NaHCO}_{3}$, which flowed at $0.7 \mathrm{ml} \mathrm{min}^{-1}$. Metrosep C 4 Guard (the guard column) and Metrosep C4 150 (the separating column) were used for the determination of cations. The mobile phase was $0.7 \mathrm{mmol} \mathrm{C}_{7} \mathrm{H}_{5} \mathrm{NO}_{4} / 1.7 \mathrm{mmol} \mathrm{HNO}_{3}$ flowing at $0.9 \mathrm{ml} \mathrm{min}^{-1}$.

Water colour determinations were performed based on the visual method against a platinum scale. Total alkalinity was determined by titration of a water sample against methyl orange indicator. The alkalinity results were then converted to $\mathrm{HCO}_{3}{ }^{-} \mathrm{mg} \mathrm{l}^{-1}$. This was done by multiplying the alkalinity results by $61 \mathrm{~g} \mathrm{~mol}^{-1}$ (where $61 \mathrm{~g} \mathrm{~mol}^{-1}$ is the molar mass of $\mathrm{HCO}_{3}{ }^{-}$). Total water hardness was determined by the versenate method. Total nitrogen was determined by Kjeldahl's method, adding to the result the nitrate and nitrite concentrations, and total phosphorus, by the molybdate method with ascorbic acid as a reducer using a Merck Spectroquant ${ }^{\circledR}$ Pharo 100 apparatus (Merck KGaA, Darmstadt, Germany).

Statistical significance of differences among study sites were tested by the non-parametric ANOVA Kruskal-Wallis $H$ test. For two groups of data, the Mann-Whitney $U$ test was applied. Spearman rank correlation was used to recognize the relationships between stable isotope composition of $C$. rudis carbonates and environmental variables. As some of them revealed inconsistencies between empirical distribution and the theoretical normal one, the nonparametric statistical procedures were chosen.
$P<0.05$ was accepted as being statistically sound. STATISTICA 8.1 software was applied.

\section{Results}

Characteristics of the properties of water and $C$. rudis stands

Environmental properties at each site studied in Lake Jasne are given in Table 1 . As it can be seen, $C$. rudis developed extensive meadows in slightly alkaline, calcium-rich waters with moderate phosphorus concentrations and mineralization. Water clarity can be considered high. Visibility measured in pelagic zone sites exceeded $4 \mathrm{~m}$ during the whole study period (overall mean $4.99 \mathrm{~m} \pm 0.4 \mathrm{SD}$ ). Lowered visibility was observed in August and September at each pelagic zone site, following a similar pattern of change with no significant differences among the sites (ANOVA Kruskal-Wallis $H$ test, $P>0.05$ ). Comparing the visibility to the depth of the studied charophyte beds (1, 1.5 and $2 \mathrm{~m}$ ), light was assumed not to be limiting for photosynthesis The species formed dense swards, covering the whole sampled areas, irrespective of the depth. The coverage lower than $100 \%$ was noted only at the site R1 in late October, although a state of atrophy at the stem base of some specimens was observed already in late September. Except for the site R1, where only $C$. rudis was found, a negligible contribution of $C$. tomentosa was noted at the two other sites. Neither the length of the main axis nor the number of branches were related to site depth or percentage volume infested by plants. PVI, however, varied between the study sites (ANOVA Kruskal-Wallis $H$ test, $P=0.0077$, Fig. 2) and revealed statistically significant negative correlation with the depth $(r=-0.76)$. It is worth emphasizing that the content of carbonate incrustation of C. rudis apices was not related to the depth, morphometric features or PVI but varied during the study period. At each studied bed, an increase in the content of $\mathrm{CaCO}_{3}$ on stems was observed until August or September with the greatest difference between June and July. Then, a decrease was observed (Fig. 3).

Regarding water properties at the sites studied (Table 1), all but one parameter revealed no statistically significant site-to-site variability during the study reported. The exception was water colour 
Table 1 Physical and chemical properties of water in C. rudis beds and at open water sites studied in Lake Jasne between June and October, 2008

\begin{tabular}{|c|c|c|c|c|c|c|}
\hline \multirow[t]{2}{*}{ Variables } & \multicolumn{6}{|l|}{ Sites } \\
\hline & $\mathrm{R} 1$ & $\mathrm{R} 2$ & $\mathrm{R} 3$ & $\mathrm{P} 1$ & $\mathrm{P} 2$ & P3 \\
\hline \multirow[t]{2}{*}{ Temperature $\left({ }^{\circ} \mathrm{C}\right)$} & $18.16 \pm 4.4$ & $18.14 \pm 4.4$ & $18.14 \pm 4.3$ & $18.14 \pm 4.3$ & $18.02 \pm 4.2$ & $18.00 \pm 4.2$ \\
\hline & $12.1-22.2$ & $12.1-22.3$ & $12.3-21.9$ & $12.2-22.1$ & $12.1-21.4$ & $12.2-21.5$ \\
\hline \multirow[t]{2}{*}{ Conductivity $\left(\mu \mathrm{S} \mathrm{cm}^{-1}\right)$} & $246.6 \pm 8.9$ & $245.6 \pm 10.3$ & $247.8 \pm 8.9$ & $246.4 \pm 10.1$ & $248.4 \pm 9.8$ & $249.4 \pm 10.3$ \\
\hline & $232-256$ & $231-256$ & $232-254$ & $232-258$ & $232-258$ & $232-259$ \\
\hline \multirow[t]{2}{*}{ Dissolved $\mathrm{O}_{2}\left(\mathrm{mg} \mathrm{l}^{-1}\right)$} & $8.88 \pm 1.4$ & $9.21 \pm 1.0$ & $9.49 \pm 1.1$ & $9.23 \pm 1.3$ & $9.34 \pm 1.2$ & $9.24 \pm 1.4$ \\
\hline & $7.1-10.8$ & $8.2-10.9$ & $8.6-11.3$ & $7.5-11.1$ & $8.0-11.2$ & $7.7-11.4$ \\
\hline \multirow[t]{2}{*}{ Colour (mg Pt $1^{-1}$ ) } & $10.3 \pm 0.4$ & $10.5 \pm 0.4$ & $10.3 \pm 0.3$ & $9.8 \pm 0.4$ & $9.9 \pm 0.2$ & $10.0 \pm 0.0$ \\
\hline & $10-11$ & $10-11$ & $10-10.5$ & $9-10$ & $9.5-10$ & $10-10$ \\
\hline \multirow[t]{2}{*}{$\mathrm{pH}$} & $8.43 \pm 0.3$ & $8.40 \pm 0.3$ & $8.45 \pm 0.3$ & $8.41 \pm 0.3$ & $8.39 \pm 0.3$ & $8.38 \pm 0.4$ \\
\hline & $8.2-8.9$ & $8.1-8.9$ & $8.2-8.9$ & $8.1-8.9$ & $8.1-8.9$ & $8.0-8.9$ \\
\hline \multirow[t]{2}{*}{ Secchi depth (m) } & - & - & - & $5.00 \pm 0.5$ & $5.00 \pm 0.4$ & $4.98 \pm 0.4$ \\
\hline & & & & $4.5-5.6$ & $4.5-5.5$ & $4.5-5.5$ \\
\hline \multirow[t]{2}{*}{ Alkalinity $\left(\mathrm{mmol} \mathrm{l}^{-1}\right)$} & $1.24 \pm 0.1$ & $1.26 \pm 0.1$ & $1.24 \pm 0.1$ & $1.32 \pm 0.1$ & $1.28 \pm 0.1$ & $1.30 \pm 0.2$ \\
\hline & $1.1-1.4$ & $1.1-1.4$ & $1.1-1.3$ & $1.2-1.4$ & $1.1-1.4$ & $1.1-1.5$ \\
\hline \multirow[t]{2}{*}{ Bicarbonates $\left(\mathrm{mg} \mathrm{l}^{-1}\right)$} & $75.64 \pm 7.0$ & $76.86 \pm 8.2$ & $79.30 \pm 11.4$ & $80.52 \pm 5.1$ & $78.08 \pm 8.0$ & $79.30 \pm 9.6$ \\
\hline & $67.1-85.4$ & $67.1-85.4$ & $67.1-97.6$ & $73.2-85.4$ & $67.1-85.4$ & $67.1-91.5$ \\
\hline \multirow[t]{2}{*}{ Total hardness $\left(\mathrm{mg} \mathrm{CaCO} \mathrm{Cl}_{3} \mathrm{I}^{-1}\right)$} & $122.90 \pm 5.5$ & $122.86 \pm 5.1$ & $122.52 \pm 5.4$ & $123.06 \pm 5.3$ & $122.82 \pm 5.4$ & $123.80 \pm 5.3$ \\
\hline & 116.2-129.0 & 116.9-128.5 & $116.0-128.3$ & 116.6-128.9 & $116.0-128.5$ & $116.7-129.1$ \\
\hline \multirow[t]{2}{*}{$\mathrm{Ca}^{2+}\left(\mathrm{mg} \mathrm{l}^{-1}\right)$} & $45.09 \pm 2.2$ & $44.99 \pm 2.2$ & $44.86 \pm 2.2$ & $45.05 \pm 2.2$ & $45.04 \pm 2.2$ & $45.37 \pm 2.0$ \\
\hline & $42.6-47.7$ & $42.5-47.5$ & $42.4-47.4$ & $42.4-47.6$ & $42.4-47.5$ & $42.6-47.5$ \\
\hline \multirow[t]{2}{*}{$\mathrm{Mg}^{2+}\left(\mathrm{mg} \mathrm{l}^{-1}\right)$} & $2.59 \pm 0.1$ & $2.59 \pm 0.1$ & $2.60 \pm 0.1$ & $2.59 \pm 0.1$ & $2.59 \pm 0.1$ & $2.58 \pm 0.1$ \\
\hline & $2.4-2.7$ & $2.4-2.7$ & $2.4-2.7$ & $2.5-2.7$ & $2.4-2.7$ & $2.5-2.7$ \\
\hline \multirow[t]{2}{*}{$\mathrm{N}-\mathrm{NH}_{4}^{+}\left(\mathrm{mg} \mathrm{l}^{-1}\right)$} & $0.135 \pm 0.02$ & $0.103 \pm 0.05$ & $0.091 \pm 0.07$ & $0.219 \pm 0.10$ & $0.144 \pm 0.11$ & $0.109 \pm 0.10$ \\
\hline & $0.10-0.17$ & $0.02-0.16$ & $0.02-0.20$ & $0.07-0.32$ & $0.04-0.30$ & $0.02-0.27$ \\
\hline \multirow[t]{2}{*}{$\mathrm{N}-\mathrm{NO}_{2}{ }^{-}\left(\mathrm{mg} \mathrm{l}^{-1}\right)$} & $0.01 \pm 0.0$ & $0.01 \pm 0.0$ & $0.01 \pm 0.0$ & $0.01 \pm 0.0$ & $0.01 \pm 0.0$ & $0.01 \pm 0.0$ \\
\hline & $0.01-0.01$ & $0.01-0.01$ & $0.01-0.01$ & $0.01-0.01$ & $0.01-0.01$ & $0.01-0.01$ \\
\hline \multirow[t]{2}{*}{$\mathrm{N}-\mathrm{NO}_{3}^{-}\left(\mathrm{mg} \mathrm{l}^{-1}\right)$} & $0.032 \pm 0.05$ & $0.030 \pm 0.04$ & $0.028 \pm 0.04$ & $0.064 \pm 0.07$ & $0.030 \pm 0.04$ & $0.036 \pm 0.06$ \\
\hline & $0.01-0.12$ & $0.01-0.11$ & $0.01-0.10$ & $0.01-0.15$ & $0.01-0.11$ & $0.01-0.14$ \\
\hline \multirow[t]{2}{*}{$\mathrm{TN}\left(\mathrm{mg} \mathrm{l}^{-1}\right)$} & $1.138 \pm 0.10$ & $1.130 \pm 0.15$ & $1.338 \pm 0.07$ & $1.152 \pm 0.08$ & $1.098 \pm 0.16$ & $1.204 \pm 0.23$ \\
\hline & $1.04-1.24$ & $0.89-1.27$ & $1.26-1.45$ & $1.04-1.27$ & $0.82-1.23$ & $0.92-1.46$ \\
\hline \multirow[t]{2}{*}{$\mathrm{P}-\mathrm{PO}_{4}{ }^{3-}\left(\mathrm{mg} \mathrm{l}^{-1}\right)$} & $0.013 \pm 0.01$ & $0.015 \pm 0.01$ & $0.022 \pm 0.01$ & $0.016 \pm 0.01$ & $0.020 \pm 0.02$ & $0.027 \pm 0.01$ \\
\hline & $0.003-0.03$ & $0.003-0.03$ & $0.010-0.03$ & $0.003-0.04$ & $0.003-0.05$ & $0.01-0.05$ \\
\hline \multirow[t]{2}{*}{$\mathrm{TP}\left(\mathrm{mg} \mathrm{l}^{-1}\right)$} & $0.033 \pm 0.01$ & $0.033 \pm 0.01$ & $0.047 \pm 0.01$ & $0.044 \pm 0.02$ & $0.044 \pm 0.02$ & $0.054 \pm 0.02$ \\
\hline & $0.02-0.05$ & $0.02-0.05$ & $0.04-0.06$ & $0.02-0.07$ & $0.03-0.07$ & $0.03-0.07$ \\
\hline \multirow[t]{2}{*}{$\mathrm{SO}_{4}^{2-}\left(\mathrm{mg} \mathrm{l}^{-1}\right)$} & $54.64 \pm 0.3$ & $54.52 \pm 0.3$ & $54.48 \pm 0.5$ & $54.52 \pm 0.4$ & $54.32 \pm 0.4$ & $54.44 \pm 0.4$ \\
\hline & $54.2-54.9$ & $54.1-54.8$ & $53.8-55$ & $53.9-55$ & $53.6-54.8$ & $54.1-55.1$ \\
\hline \multirow[t]{2}{*}{$\mathrm{Cl}^{-}\left(\mathrm{mg} \mathrm{l}^{-1}\right)$} & $11.66 \pm 0.1$ & $11.64 \pm 0.1$ & $11.68 \pm 0.1$ & $11.68 \pm 0.1$ & $11.58 \pm 0.1$ & $11.88 \pm 0.5$ \\
\hline & $11.6-11.8$ & $11.6-11.8$ & $11.5-11.8$ & $11.5-11.9$ & $11.4-11.8$ & $11.5-12.7$ \\
\hline \multirow[t]{2}{*}{$\mathrm{Na}^{+}\left(\mathrm{mg} \mathrm{l}^{-1}\right)$} & $4.554 \pm 0.07$ & $4.537 \pm 0.04$ & $4.520 \pm 0.03$ & $4.542 \pm 0.04$ & $4.519 \pm 0.06$ & $4.555 \pm 0.09$ \\
\hline & $4.48-4.64$ & $4.50-4.60$ & $4.48-4.55$ & $4.50-4.59$ & $4.44-4.60$ & $4.48-4.70$ \\
\hline \multirow[t]{2}{*}{$\mathrm{K}^{+}\left(\mathrm{mg} \mathrm{l}^{-1}\right)$} & $0.612 \pm 0.01$ & $0.602 \pm 0.03$ & $0.590 \pm 0.04$ & $0.611 \pm 0.03$ & $0.603 \pm 0.06$ & $0.638 \pm 0.10$ \\
\hline & $0.60-0.63$ & $0.56-0.63$ & $0.54-0.64$ & $0.57-0.66$ & $0.54-0.67$ & $0.56-0.79$ \\
\hline
\end{tabular}


Table 1 continued

\begin{tabular}{|c|c|c|c|c|c|c|}
\hline \multirow[t]{2}{*}{ Variables } & \multicolumn{6}{|l|}{ Sites } \\
\hline & $\mathrm{R} 1$ & $\mathrm{R} 2$ & R3 & $\mathrm{P} 1$ & $\mathrm{P} 2$ & P3 \\
\hline C. rudis cover $(\%)$ & $\begin{array}{l}96.0 \pm 8.9 \\
80-100\end{array}$ & $\begin{array}{l}100.0 \pm 0.0 \\
100-100\end{array}$ & $\begin{array}{l}100.0 \pm 0.0 \\
100-100\end{array}$ & - & - & - \\
\hline PVI $(\%)$ & $\begin{array}{l}16.1 \pm 5.0 \\
8-20\end{array}$ & $\begin{array}{l}35.0 \pm 5.0 \\
30-40\end{array}$ & $\begin{array}{l}18.7 \pm 5.6 \\
13-27\end{array}$ & - & - & - \\
\hline Axis length $(\mathrm{cm})$ & $\begin{array}{l}43.068 \pm 3.15 \\
39.83-45.77\end{array}$ & $\begin{array}{l}44.737 \pm 4.04 \\
41.15-50.48\end{array}$ & $\begin{array}{l}38.038 \pm 5.03 \\
32.44-43.82\end{array}$ & - & - & - \\
\hline No of branches & $\begin{array}{l}17.9 \pm 1.2 \\
6-40\end{array}$ & $\begin{array}{l}19.9 \pm 5.2 \\
4-47\end{array}$ & $\begin{array}{l}16.6 \pm 1.8 \\
5-40\end{array}$ & - & - & - \\
\hline Carbonate content in D.W. (\%) & $\begin{array}{l}38.011 \pm 13.88 \\
13.92-48.38\end{array}$ & $\begin{array}{l}41.019 \pm 12.31 \\
19.37-49.64\end{array}$ & $\begin{array}{l}43.963 \pm 15.18 \\
17.34-53.93\end{array}$ & - & - & - \\
\hline
\end{tabular}

Values represent mean $\pm \mathrm{SD}$ and min.-max. ranges. R1-R3, sites in C. rudis beds; P1-P3, macrophyte-free pelagic sites D. W. dry weight

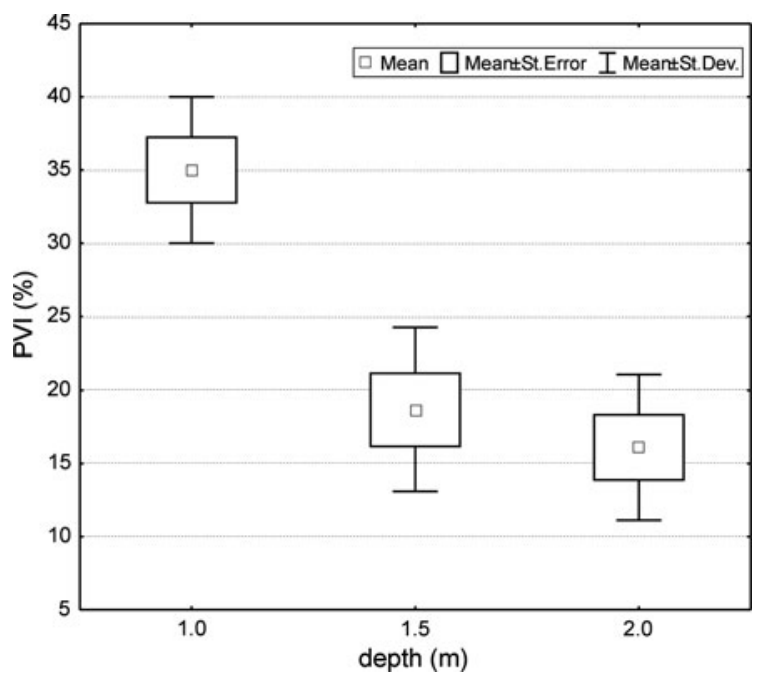

Fig. 2 Percentage volume infested (PVI) in C. rudis stands developed at different depths

(ANOVA $H$ test, $P=0.0146$ ) which was higher at sites in $C$. rudis beds. Despite the $H$ test result, the differences were rather minor (Table 1). Greater differences appeared when two groups of sites were compared: the sites in $C$. rudis with those in the pelagic zone. Most properties, particularly those related to bicarbonate concentration and water hardness, showed lower values in Chara vegetation, this being exemplified in Fig. 4. The differences, however, were not statistically significant (Mann-Whitney $U$ test, $P>0.05)$. Again, the exception was water

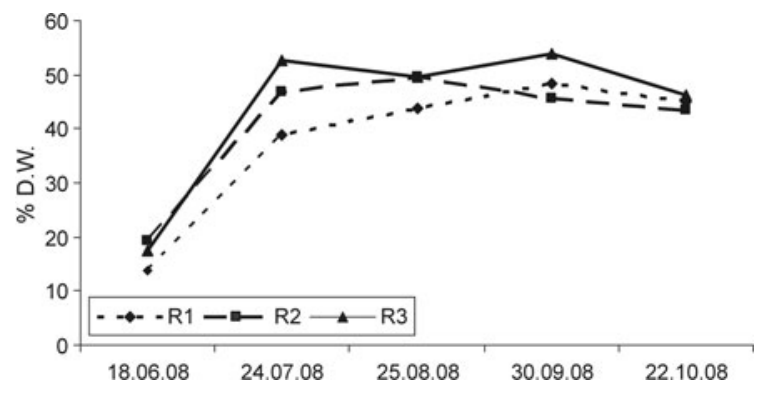

Fig. 3 Dynamics of carbonate incrustation content of $C$. rudis apices collected from sites studied in Lake Jasne. $R 1-R 3$ : sites in $C$. rudis beds. For each site and study event $N=10$

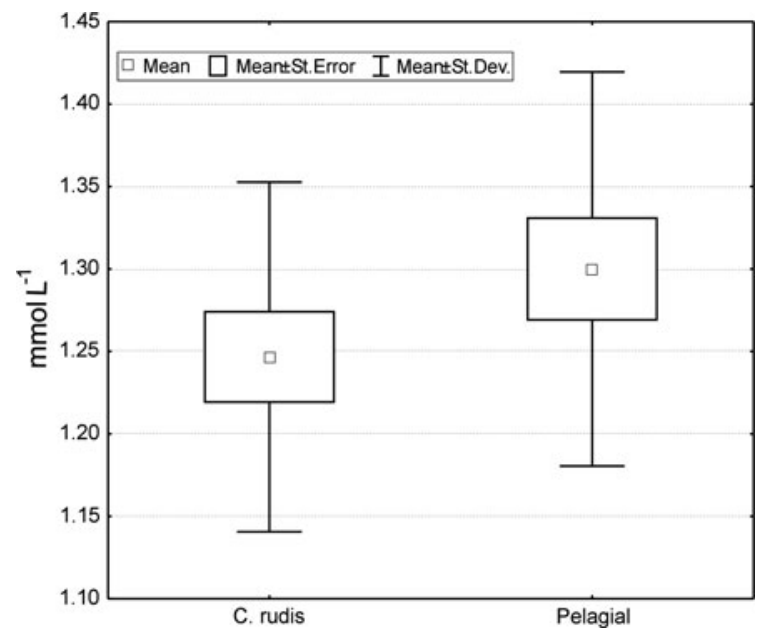

Fig. 4 Alkalinity above C. rudis stands and in macrophytefree pelagic zone studied monthly in Lake Jasne between June and October, 2008. For each group $N=15$ 
colour, slightly higher above the Chara patches $(P=0.0017)$.

Month-to-month dynamics of $\delta^{13} \mathrm{C}$ and $\delta^{18} \mathrm{O}$ values of $C$. rudis incrustation and correlation with environmental variables

The $\delta^{13} \mathrm{C}$ of the carbonate incrustation of $C$. rudis apices showed a clear increase between June and
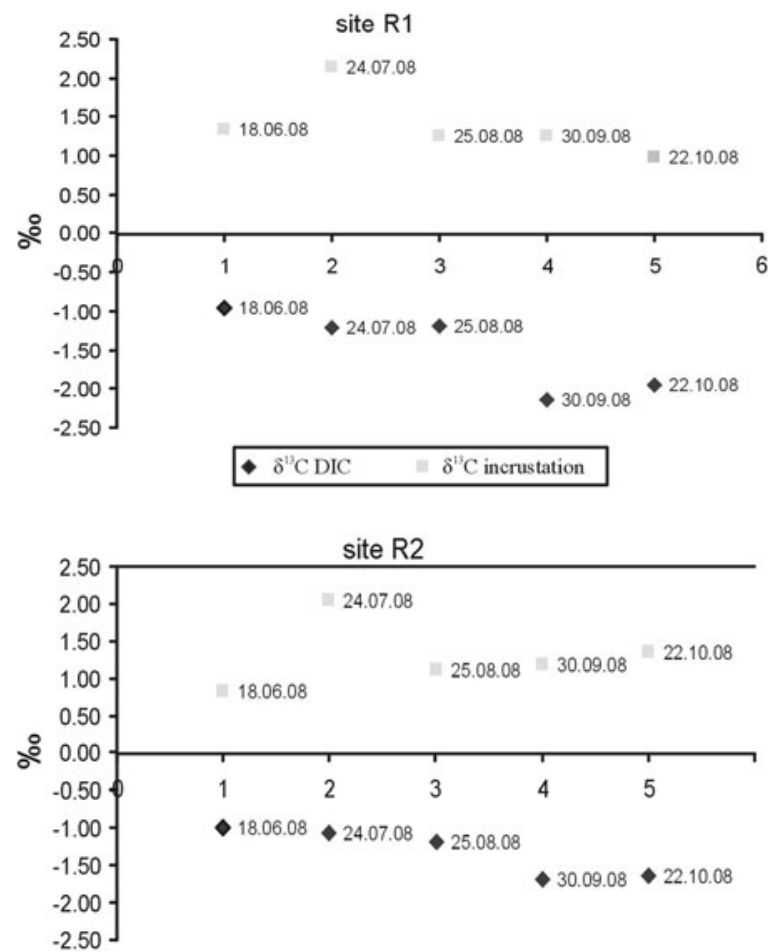

$-\delta^{13} \mathrm{C}$ DIC $\quad \delta^{19} \mathrm{C}$ incrustation

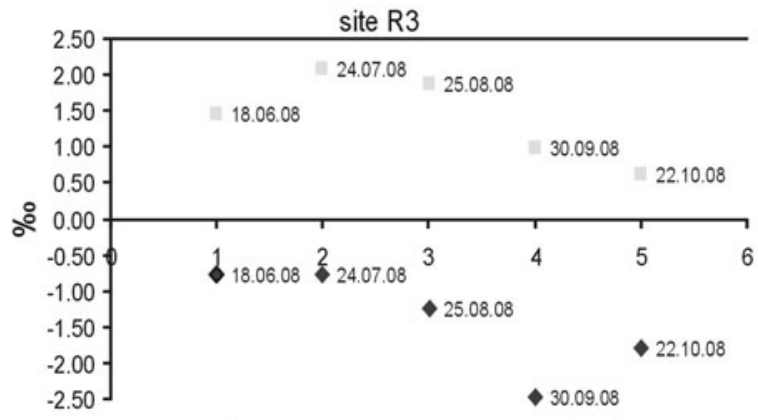

$\downarrow \delta^{13} \mathrm{C}$ DIC $\quad \delta^{13} \mathrm{C}$ incrustation
July. This tendency was apparent at each study site (Fig. 5). Then $\delta^{13} \mathrm{C}$ declined and, with the exception of the $\mathrm{R} 2$ site, the lowest values were obtained in October. The $\delta^{13} \mathrm{C}$ of dissolved inorganic carbon in water $\left(\delta^{13} \mathrm{C}_{\text {DIC }}\right)$ decreased over the same time period. Neither the $\delta^{13} \mathrm{C}$ in incrustation nor in DIC significantly varied between the studied sites (ANOVA by Kruskal-Wallis $H$ test, $P>0.05$, Table 1). The difference in $\delta^{13} \mathrm{C}$ between incrustation and DIC from above $C$. rudis exceeded $2 \%$ at each site.
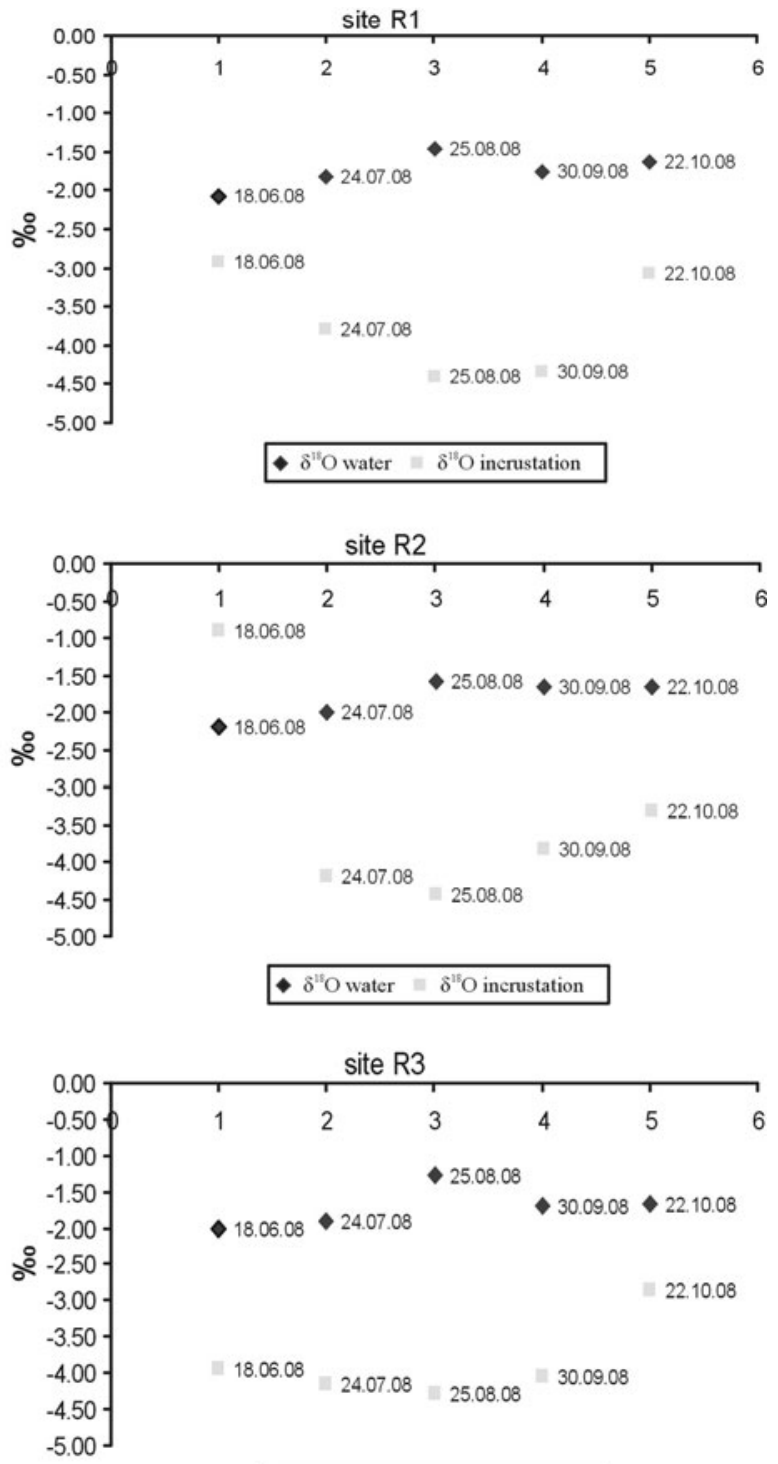

$\bullet \delta^{13} \mathrm{O}$ water $\quad \delta^{\text {is }} \mathrm{O}$ incrustation

Fig. 5 Dynamics of $\delta^{13} \mathrm{C}$ and $\delta^{18} \mathrm{O}$ in $C$. rudis incrustations and waters above $C$. rudis stands at three sites studied monthly in Lake Jasne between June and October, 2008 

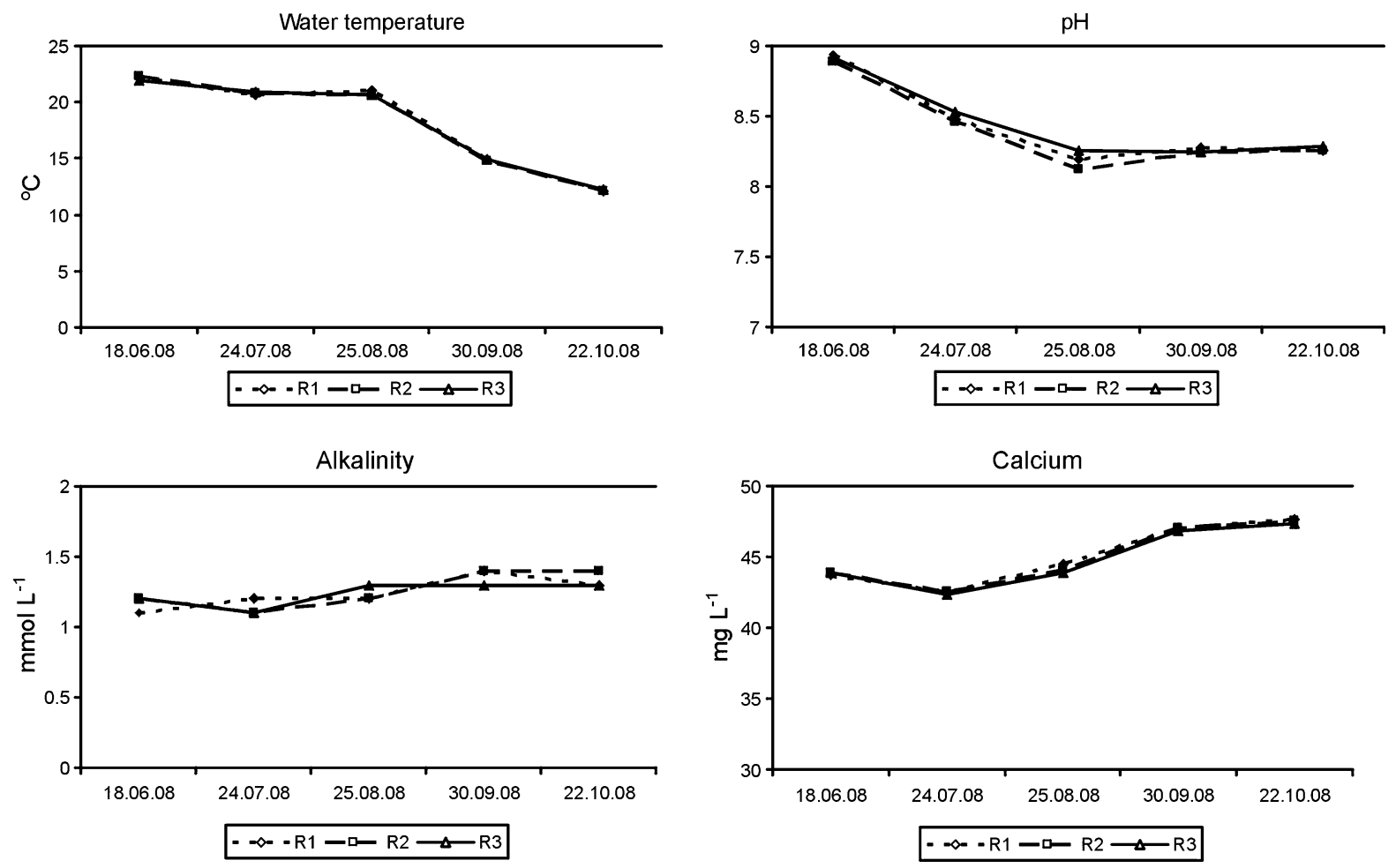

Fig. 6 Dynamics of chosen water properties above $C$. rudis stands at three sites studied monthly in Lake Jasne between June and October, 2008

Incrustation was enriched in heavier carbon isotope, ${ }^{13} \mathrm{C}$ (Fig. 5).

By contrast, water was enriched in ${ }^{18} \mathrm{O}$ (except for June at site R2, Fig. 5). The difference between $\delta^{18} \mathrm{O}$ of incrustation and water exceeded $2 \%$ between July and September. The $\delta^{18} \mathrm{O}$ of incrustation clearly decreased between June and August and, then, increased in September and October. The $\delta^{18} \mathrm{O}$ of water showed to a certain extent an inverse pattern of changes. No significant differences were found between the sites (ANOVA $H$ test, $P>0.05$ ).

Considering the stable carbon and oxygen isotope composition in water at each study site, no site-to-site differences were evident (ANOVA $H$ test, $P>0.05$ ). The differences were also statistically insignificant when two groups of data were considered: the group of sites in Chara vegetation and in the pelagic zone (Mann-Whitney $U$ test, $P>0.05$ ). Water above Chara beds was both ${ }^{13} \mathrm{C}$ and ${ }^{18} \mathrm{O}$-enriched.

Temporal changes in water chemistry (temperature, $\mathrm{pH}$, alkalinity and $\mathrm{Ca}^{2+}$ concentration) above Chara beds are presented in Fig. 6. Of all the environmental variables, $\delta^{13} \mathrm{C}$ of incrustation showed statistically significant correlations with total hardness $(r=-0.58)$ and $\mathrm{Ca}^{2+}$ concentration $(r=-0.65)$. The correlation with $\delta^{13} \mathrm{C}_{\mathrm{DIC}}$ was positive, but statistically insignificant. A negative relationship was found between $\delta^{18} \mathrm{O}$ of incrustation and water $(r=-0.54)$. The carbonate $\delta^{18} \mathrm{O}$ was negatively correlated with the mineral incrustation contribution to Chara dry weight $(r=-0.61), \mathrm{Mg}^{2+}$ concentration $(r=-0.75)$ and conductivity $(r=-0.64)$, and positively with oxygen content $(r=+0.69)$ and $\mathrm{pH}$ $(r=+0.59)$ in water. The depth of studied Chara patches, structure and PVI were not significantly correlated with carbonate isotope composition.

\section{Discussion}

Chara rudis developed compact meadows in the study Lake Jasne and was a dominant component of the vegetation compared with other macrophyte species, particularly vascular species. The water 
chemistry parameters place the lake in the group of ecosystems with moderate nutrient availability and high transparency, resulting in characterisation of the lake as mesotrophic (Carlson, 1977, Pełechaty et al., 2007). Good light conditions, along with calcium and bicarbonate availability, promote charophytes in submerged vegetation (Dąmbska, 1964; Hutchinson, 1975; Krause, 1981, 1997; Blindow, 1992a, b). Thus, in the study lake, dense charophyte beds formed a significant cover on the $\mathrm{CaCO}_{3}$-rich substratum. This suggests that the lake offers good conditions for the charophyte-related carbonate precipitation. This is corroborated by alkalinity values that were lower in the charophyte meadows than in the macrophyte-free pelagic zone (Fig. 4). Photosynthetic activity of charophytes results not only in calcium and bicarbonate depletion in the surrounding waters, but also in the phosphorus co-precipitation with carbonates, and nutrients incorporation in biomass (Kufel \& Kufel, 2002 and references therein). Although charophytes are considered very effective in modifying water properties (van den Berg et al., 1998), the parameters determined in this study above the chosen patches of $C$. rudis reflected lake characteristics and so, were lake- rather than site-specific, which might have resulted from morphometric features of Lake Jasne. The maximum and mean depths place the lake in a transitional type between typical shallow and stratified lakes, which suggests a primary role of wind-induced water movement in surface disturbance. Frequent water mixing may make the water chemistry uniform within the lake, similar at each study site and temporarily, rather than spatially variable (Pełechaty, 2006).

The studied charophyte beds were floristically poor and overgrown by $C$. rudis, whose coverage did not differ among the sites and sampling events. Since, then the constant coverage might have been more important for PVI values, obviously dependent on the depth (Fig. 2), rather than the charophyte morphology, not linked directly with the site characteristics. Since the content of carbonate incrustation was determined in the apices of $C$. rudis, no relation was found with the site depth, $C$. rudis morphology or PVI. By contrast, carbonates varied during the study period, following similar pattern of changes at each study site (Fig. 3). This emphasizes the importance of photosynthetic intensity for carbonate precipitation, rapidly increasing at the beginning of summer season and declining in the autumn. If charophyte growth, most intense photosynthesis and precipitation of calcium carbonate are restricted to the apical parts of thalli (Andrews et al., 1984; Coletta et al., 2001), our results suggest that the community structure may be of minor importance for carbonate formation. Light availability, mineral content of water and climate conditions, influencing photosynthetic activity, appear to be the crucial factors. However, the density of plants and area covered by charophyte meadows, apart from their obvious importance for the total carbonate deposition in the sediments, may become significant at the peak growing season, when high photosynthetic rates may affect the chemistry of water, depleting calcium and bicarbonate concentration. In the region where the study reported was performed (mid-Western Poland), we observed lower summer calcium concentrations in lakes with diverse and abundant charophyte vegetation as compared to those with minor contribution of charophytes (Pełechaty et al., 2007).

The influence of photosynthesis can also explain why water above $C$. rudis beds was ${ }^{13} \mathrm{C}$-enriched, comparing to the pelagic zone. Preferential uptake of ${ }^{12} \mathrm{CO}_{2}$ for photosynthetic purposes could have led to a higher rate of heavier isotope in the water. However, the discrepancy in $\delta^{13} \mathrm{C}_{\text {DIC }}$ was not pronounced. Differences in $\delta^{18} \mathrm{O}_{\text {WATER }}$ above the studied charophyte patches and in the pelagic zone were also statistically insignificant showing evenly distributed values of $\delta^{18} \mathrm{O}$ within surface waters. Under the environmental conditions observed, progressive photosynthetic removal of isotopically light carbon by extensive charophyte meadows reaching up to $60 \%$ of the lake area (Pełechaty et al., 2007), causes strong ${ }^{13} \mathrm{C}$-enrichment of DIC, reflected in the measured $\delta^{13} \mathrm{C}_{\text {DIC }}$ values (Fig. 5). During intense photosynthesis, the water becomes depleted in dissolved $\mathrm{CO}_{2}$ (Herczeg \& Fairbanks 1987). When this occurs, $\mathrm{CO}_{2}$ enters water from the atmosphere. In conditions of an isotopic equilibrium with atmospheric $\mathrm{CO}_{2}\left(\delta^{13} \mathrm{C}\right.$ ca. $-7.8 \%$, Leng \& Marshall, 2004) $\delta^{13} \mathrm{C}_{\text {DIC }}$ amounts to about 1.3 and $0.7 \%$, at 15 and $20^{\circ} \mathrm{C}$, respectively (Mook et al. 1974). $\delta^{13} \mathrm{C}_{\text {DIC }}$ measured in the waters of Lake Jasne is isotopically lighter than this (between -0.8 and $-2.5 \%$ ), and this shows that DIC is not in an isotopic equilibrium with atmospheric $\mathrm{CO}_{2}$. 
Mean $\delta^{18} \mathrm{O}$ of waters in Lake Jasne equals about $-1.8 \%$ and is strongly enriched in ${ }^{18} \mathrm{O}$ compared to the average $\delta^{18} \mathrm{O}$ of local shallow groundwaters, amounting to ca. $-9.2 \%$ (d'Obryn et al., 1997). A shift to heavier oxygen isotope composition of waters may have resulted from the lake morphology, as it is a small and shallow water body with no surface inflow and temporal outflow, inactive during the study. However, mean yearly $\delta^{18} \mathrm{O}_{\text {WATER }}$ is expected to be isotopically lighter than mean $\delta^{18} \mathrm{O}_{\mathrm{WATER}}$ measured $(-1.8 \%)$, since the period investigated in this study is restricted to 5 months, including three with the highest mean air temperature during the year, that is commonly characterized by ${ }^{18} \mathrm{O}$-enriched waters.

Stable carbon isotope composition of the $C$. rudis carbonate incrustation followed the pattern of monthto-month changes similar to that of carbonate content. An increase in $\delta^{13} \mathrm{C}$ observed during the early summer is a result of an intense photosynthetic activity of $C$. rudis. Due to higher proportion of ${ }^{12} \mathrm{CO}_{2}$ incorporated preferentially during photosynthesis, the remaining DIC becomes ${ }^{13} \mathrm{C}$-enriched, and results in isotopically heavier calcite precipitated as an incrustation (cf. Pentecost \& Spiro, 1990; Andrews et al., 1997). A subsequent decline in $\delta^{13} \mathrm{C}$ in Chara carbonates and DIC (Fig. 5) may be explained in two ways: (a) by August the primary production diminished, and hence ${ }^{12} \mathrm{CO}_{2}$ uptake decreased. The inflowing waters supplying the lake, not influenced by photosynthesis, had a diluting effect on carbon isotope composition of DIC and resulted in $\delta^{13} \mathrm{C}_{\text {DIC }}$ decrease; (b) it is also possible that isotopically light carbon might have been partially recycled by decomposition of organic matter produced during the spring and early summer, e.g. decomposition of phytoplankton sinking through the water column. Decomposition of $C$. rudis thalli did not play a role as no sign of atrophy at the stem base was observed until late September when ${ }^{12} \mathrm{C}$ enrichment in DIC was noted.

It is important that the differences between carbonates and water above the studied beds exceeded $2 \%$. That was particularly evident in the case of the carbon isotope record. In all cases but one the difference in $\delta^{13} \mathrm{C}$ between DIC and incrustation exceeded 2.2\%o during the whole study period (Fig. 5), with $\delta^{13} \mathrm{C}_{\text {CHARA }}$ usually from 2.3 to $3.1 \%$ higher than carbon isotope value of the DIC. Experimental studies show that $\delta^{13} \mathrm{C}_{\mathrm{CALCITE}}$ is around
$1-1.5 \%$ less negative than the DIC value (Emrich et al., 1970; Romanek et al., 1992), which decreases the difference in carbon isotope values measured in Chara incrustations and DIC. The data indicate a state of disequilibrium during calcite precipitation on C. rudis stems leading to ${ }^{13} \mathrm{C}$-enrichment in carbonate. However, it is important to note that site-specific isotope composition of DIC is created by charophyte photosynthetic activity closest to Chara thalli (within Chara beds, in particular). It is possible that DIC in surface waters $(0.5 \mathrm{~m}$ deep) is influenced less than DIC of the Chara immediate environment and thus, is ${ }^{13} \mathrm{C}$-depleted in comparison to incrustations. Still, most authors agree that $\delta^{13} \mathrm{C}$ in Chara incrustations is subject to significant photosynthetically driven metabolic effects (Andrews et al., 2004, and references therein).

Table 2 presents oxygen stable isotope data of water and incrustation as well as water temperature measured and calculated using Kim \& O'Neil

Table 2 Difference between water temperature calculated $\left(T_{\mathrm{C}}\right)$ on the basis of $\delta^{18} \mathrm{O}_{\mathrm{WATER}}$ and $\delta^{18} \mathrm{O}_{\mathrm{CHARA}}$ (Kim \& O'Neil equation re-expressed by Leng \& Marshall, 2004) and measured $\left(T_{\mathrm{M}}\right)$ in $C$. rudis beds studied in Lake Jasne between June and October, 2008

\begin{tabular}{|c|c|c|c|c|c|}
\hline Site & $\delta^{18} \mathrm{O}_{\text {WATER }}$ & $\delta^{18} \mathrm{O}_{\text {CHARA }}$ & $T_{\mathrm{C}}\left({ }^{\circ} \mathrm{C}\right)$ & $T_{\mathrm{M}}\left({ }^{\circ} \mathrm{C}\right)$ & $T_{\mathrm{C}}-T_{\mathrm{M}}$ \\
\hline \multicolumn{6}{|c|}{ June 2008} \\
\hline $\mathrm{R} 1$ & -2.25 & -2.92 & 16.91 & 22.2 & -5.3 \\
\hline $\mathrm{R} 2$ & -2.37 & -0.91 & 7.29 & 22.3 & -15.0 \\
\hline $\mathrm{R} 3$ & -2.18 & -3.95 & 22.17 & 21.9 & 0.3 \\
\hline \multicolumn{6}{|c|}{ July 2008} \\
\hline $\mathrm{R} 1$ & -1.82 & -3.80 & 23.18 & 20.6 & 2.6 \\
\hline $\mathrm{R} 2$ & -1.99 & -4.21 & 24.32 & 20.8 & 3.5 \\
\hline $\mathrm{R} 3$ & -1.91 & -4.15 & 24.45 & 20.9 & 3.6 \\
\hline \multicolumn{6}{|c|}{ August 2008} \\
\hline $\mathrm{R} 1$ & -1.46 & -4.41 & 27.97 & 21.0 & 7.0 \\
\hline $\mathrm{R} 2$ & -1.58 & -4.43 & 27.50 & 20.7 & 6.8 \\
\hline $\mathrm{R} 3$ & -1.27 & -4.29 & 28.32 & 20.7 & 7.6 \\
\hline \multicolumn{6}{|c|}{ September 2008} \\
\hline $\mathrm{R} 1$ & -1.77 & -4.34 & 26.11 & 14.9 & 11.2 \\
\hline $\mathrm{R} 2$ & -1.66 & -3.82 & 24.07 & 14.8 & 9.3 \\
\hline $\mathrm{R} 3$ & -1.68 & -4.04 & 25.06 & 14.9 & 10.2 \\
\hline \multicolumn{6}{|c|}{ October 2008} \\
\hline $\mathrm{R} 1$ & -1.64 & -3.08 & 20.57 & 12.1 & 8.5 \\
\hline $\mathrm{R} 2$ & -1.66 & -3.31 & 21.55 & 12.1 & 9.5 \\
\hline $\mathrm{R} 3$ & -1.67 & -2.87 & 19.42 & 12.3 & 7.1 \\
\hline
\end{tabular}


(1997) equation re-expressed by Leng \& Marshall (2004):

$$
\begin{aligned}
T\left({ }^{\circ} \mathrm{C}\right)= & 13.8-4.58\left(\delta_{\mathrm{CARB}}-\delta_{\mathrm{WATER}}\right) \\
& +0.08\left(\delta_{\mathrm{CARB}}-\delta_{\mathrm{WATER}}\right)^{2}
\end{aligned}
$$

Significant discrepancies can by seen between the temperature measured $\left(T_{\mathrm{M}}\right)$ and calculated $\left(T_{\mathrm{C}}\right)$ that can be interpreted as resulting from oxygen isotope disequilibrium during carbonate precipitation. However, it is important to note that temperature as well as $\delta^{18} \mathrm{O}_{\text {WATER }}$ were measured in waters at $0.5 \mathrm{~m}$ depth, while Chara beds studied occurred at 1.0, 1.5 and $2.0 \mathrm{~m}$. Oxygen stable isotope signatures of surface waters may be, and probably are, ${ }^{18} \mathrm{O}-$ enriched (due to preferential evaporation of $\mathrm{H}_{2}^{16} \mathrm{O}$ molecules, e.g. $\mathrm{Li} \& \mathrm{Ku}, 1997)$ in comparison to waters within Chara patches. Decreasing $\delta^{18} \mathrm{O}_{\text {WATER }}$ used in calculations only by 0.8 and $1.2-1.5 \%$ for July and August, respectively, brings $T_{\mathrm{C}}$ very close to $T_{\mathrm{M}}$. Differences between $T_{\mathrm{C}}$ and $T_{\mathrm{M}}$ increase from July to September and decrease in October. This, according to our suggestions, indicates the strongest influence of evaporation on $\delta^{18} \mathrm{O}$ surface waters in summer months.

It is also crucial to note that $\delta^{18} \mathrm{O}_{\text {CHARA }}$ measured in this study refers to incrustation formed at the apical part of Chara stems and thus reflects $\delta^{18} \mathrm{O}_{\text {WATER }}$ and water temperature during the month preceding the moment of water collection and temperature measuring. This is evident in the data collected in September, where $T_{\mathrm{M}}$ (ca. $14.9^{\circ} \mathrm{C}$ ) is probably lower than the actual temperature in which Chara incrustations precipitated during the preceding month. This is a possible reason why the discrepancy between $T_{\mathrm{C}}$ and $T_{\mathrm{M}}$ increases in September.

Considering the discussion, it can be suggested that incrustations may precipitate in isotopic equilibrium with ambient waters within Chara beds, and the discrepancy between $T_{\mathrm{C}}$ and $T_{\mathrm{M}}$ (Table 2) is caused by ${ }^{18} \mathrm{O}$-enrichment of surface waters.

Our study pointed at the relationships between the stable isotope composition and the water chemistry during calcite precipitation and the content of mineral incrustation. Although the linkage with the content of carbonate incrustation seems obvious, it was only statistically significant for the $\delta^{18} \mathrm{O}$. The negative correlation of $\delta^{18} \mathrm{O}$ in incrustation and Chara dry weight may be explained as a consequence of kinetic isotope effects that result from discrimination against the heavy isotopes of oxygen during the hydration and hydroxylation of $\mathrm{CO}_{2}$ (McConnaughey, 1989). Rapid precipitation of $\mathrm{CaCO}_{3}$ in conditions of intense photosynthesis, e.g. within dense Chara beds, is associated with strong disequilibrium leading to depletion of ${ }^{18} \mathrm{O}$ in carbonates (McConnaughey, 1989, and references therein). Hence, $\delta^{18} \mathrm{O}$ values in stem incrustation are not equilibrium values, being offset to isotopically lighter compositions relative to equilibrium. This contradicts the suggestion made above describing a possible state of isotope equilibrium during precipitation of Chara incrustation. Andrews et al. (2004) assess the offset as about $1.5 \%$. In this study, the discrepancy observed between $\delta^{18} \mathrm{O}$ in incrustations and water is greatest between July and September with a peak in August (Fig. 5). Such a record is due to coexistence of two opposite processes influencing oxygen isotope values, i.e. evaporation resulting in ${ }^{18} \mathrm{O}$-enrichment in water and a kinetic effect during rapid precipitation of calcite on stems causing ${ }^{18} \mathrm{O}$-depletion of carbonates.

It is important to note that kinetic isotope effects during intense photosynthesis also influence carbon isotopes. The kinetic depletion of ${ }^{13} \mathrm{C}$ in carbonates may even mask the photosynthetic ${ }^{13} \mathrm{C}$-enrichment in carbonate and result in $\delta^{13} \mathrm{C}$ of the carbonate isotopically lighter than $\delta^{13} \mathrm{C}_{\mathrm{DIC}}$ (McConnaughey, 1989). However, the latter is not the case in C. rudis incrustations in Lake Jasne (Fig. 5). Still, kinetic isotope effects could and probably did result in $\delta^{13} \mathrm{C}$ in incrustation closer to $\delta^{13} \mathrm{C}_{\mathrm{DIC}}$ in comparison to conditions of slow $\mathrm{CaCO}_{3}$ precipitation during slow or moderately intense photosynthesis.

In agreement with Coletta et al. (2001), our results showed that the $\delta^{13} \mathrm{C}$ of the carbonate incrustation of C. rudis apices was heavier than the DIC. The opposite was found for the $\delta^{18} \mathrm{O}$ (Fig. 5). The authors cited provided data for $C$. hispida $\mathrm{L}$. Both charophyte species are closely related ( $C$. rudis is often considered a variety of $C$. hispida), and the results can be assumed as comparable. As compared to C. hispida, C. rudis and water above the studied beds appeared to be far more enriched in heavier carbon isotope. It was also the case for oxygen isotope, but the difference was smaller. In our opinion, different times of collection and different types of aquatic environments in particular, combined with varied photosynthesis rate may explain the inconsistencies found. Coletta et al. (2001) provided also the data on the 
stable isotope composition in other charophyte species, including $C$. rudis (exactly $C$. hispida var. rudis, Coletta et al., 2001). Interestingly, the results given for the last species are comparable to our results. As our data are limited to one species, further study is needed to find out if the correlations observed here are of broader significance.

Acknowledgments The study was financed by Polish Ministry of Science and Higher Education as project No. N N305 337534. Two anonymous peer reviewers are kindly acknowledged for their precious comments which helped to improve the manuscript.

Open Access This article is distributed under the terms of the Creative Commons Attribution Noncommercial License which permits any noncommercial use, distribution, and reproduction in any medium, provided the original author(s) and source are credited.

\section{References}

Alimov, A. F., 2003. Towards a Theory of the Functioning of Aquatic Ecosystems. Backhuys Publishers, Leiden.

Andrews, M., I. R. Davidson, M. E. Andrews \& J. A. Raven, 1984. Growth of Chara hispida. I. Apical growth and basal decay. Journal of Ecology 72: 873-884.

Andrews, J. E., R. Riding \& P. F. Dennis, 1997. The stable isotope record of environmental and climatic signals in modern terrestrial microbial carbonates from Europe. Palaeogeography, Palaeoclimatology, Palaeoecology 129: 171-189.

Andrews, J., P. Coletta, A. Pentecost, R. Riding, S. Dennis, P. F. Dennis \& B. Spiro, 2004. Equilibrium and disequilibrium stable isotope effects in modern charophyte calcites: implications for palaeoenvironmental studies. Palaeogeography, Palaeoclimatology, Palaeoecology 204: 101-114.

Blindow, I., 1992a. Decline of charophytes during eutrophication; a comparison to angiosperms. Freshwater Biology 28: 9-14.

Blindow, I., 1992b. Long and short term dynamics of submerged macrophytes in two shallow eutrophic lakes. Freshwater Biology 28: 15-27.

Braun-Blanquet, J., 1964. Pflanzensoziologie, Grundzüge der Vegetationskunde. 3 Aufl. Springer, Wien.

Carlson, R. E., 1977. A trophic state index for lakes. Limnology and Oceanography 22: 361-369.

Coletta, P., A. Pentecost \& B. Spiro, 2001. Stable isotopes in charophyte incrustations: relationships with climate and water chemistry. Palaeogeography, Palaeoclimatology, Palaeoecology 173: 9-19.

D’Obryn, K., J. Grabczak \& A. Zuber, 1997. Mapy składów izotopowych infiltracji holoceńskiej na obszarze Polski. [Maps of isotopic composition of the Holocene meteoric waters in Poland. In Polish]. In Górski, J. \& E. Liszkowska (eds), Współczesne Problemy Hydrogeologii 8: 331-333.
Dąmbska, I., 1964. Charophyta-ramienice. [CharophytaStoneworts. In Polish]. Państwowe Wydawnictwo Naukowe, Warszawa.

Dittrich, M. \& M. Obst, 2004. Are picoplankton responsible for calcite precipitation in lakes? Royal Swedish Academy of Sciences. Ambio 33: 559-564.

Dittrich, M., P. Kurz \& B. Wehrli, 2004. The role of autotrophic picocyanobacteria in calcite precipitation in oligotrophic lake. Geomicrobiology Journal 21: 45-53.

Emrich, K., D. H. Ehhalt \& J. C. Vogel, 1970. Carbon isotope fractionation duringthe precipitation of calcium carbonate. Earth and Planetary Science Letters 8: 363-371.

Gillikin, D. P. \& S. Bouillon, 2007. Determination of $\delta^{18} \mathrm{O}$ of water and $\delta^{13} \mathrm{C}$ of dissolved inorganic carbon using a simple modification of an elemental analyzer-isotope ratio mass spectrometer: an evaluation. Rapid Communications in Mass Spectrometry 21: 1475-1478.

Groves, J. \& G. R. Bullock-Webster, 1924. The British Charophyta. Vol. II: Charae. Ray Society, London.

Herczeg, A. L. \& R. G. Fairbanks, 1987. Anomalous carbon isotope fractionation between atmospheric $\mathrm{CO}_{2}$ and dissolved inorganic carbon induced by intense photosynthesis. Geochimica Cosmochimica Acta 51: 895-899.

Hutchinson, G. E., 1975. A Treatise on Limnology, Vol. 3: Limnological Botany. Wiley; Chapman and Hall, Ltd., New York; London.

Jańczak, J. (ed.), 1996. Atlas jezior Polski. Tom I. Jeziora Pojezierza Wielkopolskiego i Pomorskiego w granicach dorzecza Odry. [Atlas of Polish lakes. Vol. I. Lakes of Pojezierze Wielkopolskie and Pomorskie lakelands within the Odra basin. In Polish]. Instytut Meteorologii i Gospodarki Wodnej, Bogucki Wydawnictwo Naukowe, Poznań.

Kim, S. T. \& J. R. O’Neil, 1997. Equilibrium and nonequilibrium oxygen isotope effects in synthetic carbonates. Geochimica et Cosmochimica Acta 61: 3461-3475.

Krause, W., 1997. Charales (Charophyceae). Süsswasserflora von Mitteleuropa, Band 18. Gustav Fischer, Jena.

Krause, W., 1981. Characeen als Bioindicatoren für den Gewässerzustandt. Limnologica (Berlin) 13: 399-418.

Kufel, L. \& I. Kufel, 2002. Chara beds acting as nutrient sinks in shallow lakes-a review. Aquatic Botany 72: 249-260.

Leng, M. J. \& J. D. Marshall, 2004. Palaeoclimate interpretation of stable isotope data from lake sediment archives. Quaternary Science Reviews 23: 811-831.

$\mathrm{Li}$, H. C. \& T. L. Ku, 1997. $\delta^{13} \mathrm{C}-\delta^{18} \mathrm{O}$ covariance as a paleohydrological indicator for closed-basin lakes. Palaeogeography, Palaeoclimatology, Palaeoecology 133: 69-80.

McConnaughey, T., 1997. Acid secretion, calcification, and photosynthetic carbon concentrating mechanisms. Canadian Journal of Botany 76: 1119-1126.

McConnaughey, T., 1989. ${ }^{13} \mathrm{C}$ and ${ }^{18} \mathrm{O}$ isotopic disequilibium in biological carbonates: I. Patterns. Geochimica Cosmochimica Acta 53: 151-162.

Mook, W. G., J. C. Bommerson \& W. H. Staverman, 1974. Carbon isotope fractination between dissolved bicarbonate and gaseous carbon dioxide. Earth and Planetary Science Letters 22: 169-176.

Pełechaty, M., 2006. Do physical-chemical water properties reflect the macrophyte and open water induced spatial 
heterogeneity of a shallow lake? Oceanological and Hydrobiological Studies 15: 369-386.

Pełechaty, M., A. Pełechata \& A. Pukacz, 2007. Flora i roślinność ramienicowa na tle stanu trofii jezior Pojezierza Lubuskiego (środkowo-zachodnia Polska). [Charophyte flora and vegetation against the background of the trophy state of Lubuskie Lakeland, mid-Western Poland]. Uniwersytet im. Adama Mickiewicza w Poznaniu. Bogucki Wydawnictwo Naukowe, Poznań.

Pentecost, A. \& B. Spiro, 1990. Stable carbon and oxygen isotope composition of calcite associated with modern freshwater cyanobacteria and algae. Geomicrobiology Journal 8: 17-26.

Pentecost, A., J. E. Andrews, P. F. Dennis, A. Marca-Bell \& S. Dennis, 2006. Charophyte growth in small temperate water bodies: Extreme isotopic disequilibrium and implications for the palaeoecology of shallow marl lakes. Palaeogeography, Palaeoclimatology, Palaeoecology 240: 389-404.

Raven, J. A., F. A. Smith \& N. A. Walker, 1986. Biomineralization in the Charophyceae sensu lato. In Leadbeater, B. S. C. \& R. Riding (eds), Biomineralization in lower plants and animals. Clarendon, Oxford: 550-557.
Romanek, C. S., E. L. Grossman \& J. W. Morse, 1992. Carbon isotope fractionation in synthetic aragonite and calcite: Effects of temperature and precipitation rate. Geochimica Cosmochimica Acta 56: 419-430.

Schubert H. \& I. Blindow (eds), 2003. Charophytes of the Baltic Sea. The Baltic Marine Biologists Publication No. 19. A. R. G. Ganter Verlag, Ruggell.

van den Berg, M. S., M. Scheffer, H. Coops \& J. Simons, 1998. The role of Characean algae in the management of eutrophic shallow lakes. Journal of Phycology 34: 750-756.

van den Berg, M. S., M. Scheffer, E. Van Nes \& H. Coops, 1999. Dynamics and stability of Chara sp. and Potamogeton pectinatus. Hydrobiologia 408(409): 335-342.

Wachter, E. \& J. M. Haye, 1985. Exchange of oxygen isotopes in carbon-dioxide-phosphoric acid systems. Chemical Geology 52: 365-374.

Wetzel, R. G., 1960. Marl encrustation on hydrophytes in several Michigan lakes. Oikos 11: 223-236.

Yates, K. K. \& L. L. Robbins, 1998. Production of carbonate sediments by a unicellular green alga. American Mineralogist 83: 1503-1509. 